\title{
ANALISISBIAYA BAN VULKANISIR DENGAN METODE ROADTEST PADA PERUSAHAAN ANGKUTAN BARANG PT. JTI
}

\author{
Ethys Pranoto ${ }^{1}$, Syiham Ahmad² \\ 1ProgamStudi Teknik Keselamatan Otomotif, PoliteknikKeselamatanTransportasi Jalan \\ ${ }^{2}$ ProgamStudi Teknik Keselamatan Otomotif, PoliteknikKeselamatanTransportasi Jalan \\ Email: 1ethys@pktj.ac.id \\ Email: ${ }^{2}$ syihamahmad65@gmail.com
}

\begin{abstract}
ABSTRAK
Kajian yang dilakukan karena meningkatnya penggunaan dan produksi dari ban vulkanisir seiring diperbolehkannya atau dicabutnya larangan penggunaan ban vulkanisir baik untik kendaraan penumpang maupun kendaraan komersial atau niaga. Kajian ini dilakukan terhadap ban vulkanisir pada kendaraan komersial yaitu truk. Pengujian dilakukan dengan metode roadtest guna mengetahui laju keausan tread dari ban vulkanisir. Ban vulkanisir diukur nilai keekonomisannya dengan tetap memperhatikan ambang batas ketentuan ban. Pemenuhan ketentuan ambang batas ban guna mewujudkan kendaraan yang berkeselamatan. Hasil pengujian menunjukkan adanya perbedaan laju keausan dari masing-masing ban vulkanisir. Penentuan ban vulkanisir yang digunakan pada kendaraanakanmempengaruhi biaya operasional kendaraan.
\end{abstract}

Kata kunci: roadtest, tread, dan vulkanisir

\section{PENDAHULUAN}

Industri jasa transportasi jalan baik pengangkutan penumpang maupun barang sangat bertumpu pada kesiapan dari armada atau kendaraan. Salah satu komponen kendaraan yang mendapat perhatian penting adalah ban. Ban dalam industry angkutan adalah komponen yang sering mengalami pergantian sehingga merupakan komponen yang mempengaruhi biaya operasional kendaraan.

Ban pada kendaraan memiliki empa tfungsi, yaitu: menopang beban kendaraan, menyalurkan gaya akselerasi dan pengereman kejalan, mengubah atau menjaga arah kendaraan dan menyerap kejutan dari permukaan jalan. Selain mendefinisikan fungsi ban, Bridgestone menentukan tujuh criteria unjuk kerja dari ban yaitu: efisiensi bahan bakar, usia pakai, cengkraman kering, cengkraman basah, kestabilan mengemudi, kenyamanan berkendara dan kebisingan.[3].

Ban merupakan komponen kendaraan yang selalu bergesekan dengan jalan. Selama kendaraan beroperasi di jalan maka potensi kegagalan ban dapa tterjadi. Salah satu contoh kecelakaan yang terjadi akibat ban pecah adalah kecelakaan yang menimbulkan korban jiwa. Kali iniberada di Tol Jagorawi. Kecelakaan dipicu karena salah satu mobil MPV mengalami pecah ban. Disebutkan, terdapattiga korban jiwa akibat kecelakaan ini.[4]. Kegagalan ban ketika kendaraan beroperasi tidak hanya menimbulkan kerugian materi tetapi menimbulkan korban jiwa.Kecelakaan yang disebabkan oleh pecah ban 
tidak hanya terjadi pada mobil penumpang tetapi dapat terjadi pada bus dan mobilkomersial.

Pertimbangan bahwa ban mempengaruhi biaya operasional kendaraan dan menjaga keselamatan dalam berkendara maka muncul ban vulkanisir sebagai alternative bagi dunia industry jasa transportasi. Ban vulkanisir sendiri dilarang peggunaannya di Indonesia berdasarkan Peraturan Direktur Jenderal Perhubungan Darat Nomor: SK. 523/AJ.402/DRJD/2015 tentang Pedoman Pelaksanaan Inspeksi Keselamatan Lalu Lintas dan Angkutan Jalan Bidang Angkutan Umum. Namun demikian sejak tanggal 15 Mei 2017 ditetapakan Surat Keputusan Dirjen Nomor: SK.2574/AJ.403/DRJD/2017 Tentang Pedoman Pelaksanaan Inspeksi Keselamatan Lalu Lintas Dan Angkutan Jalan tidak disebutkan lagi tentang pelarangan penggunaan ban vulkanisir. Pencabutan larangan ban vullkanisir meningkatkan penggunaan dan produksi ban vulkanisir, berdasarkan laman Bisnis Indonesia disebutkan Produksi ban vulkanisir pada 2017 mencapai 20,48 juta unit atau meningkat 2,95\% dari produksi 2016 sebanyak 19,9 juta unit. Adapun, produksi 2016 naik 4,97\% disbanding produksi di 2015 sebanyak 18,95 juta unit dan Industri vulkanisir ban dalam negeri memiliki utilitas sebesar $80 \%$ [2].

Proses vulkanisir juga dapat memperbaiki sobekan kecil atau cacat dinding samping ban, beads dan tusukan dalam satu tahap. Sebuah ban dapat di vulkanisir atau tidak, ini sepenuhnya bergantung pada jenis penggunaan ban dan kondisi ban misalnya ban mobil, 2 atau 3 kali; ban truk ringan 4 hingga 5 kali; ban trukberat 8 hingga 9 kali; ban pesawat terbang hingga 14 kali [1].

Penggunaan ban vulkanisir juga berdampak pada lingkungan dalam hal ini dampak setelah ban tidak dipakai akan menjadi sampah serta pada proses produksi akan mempengaruhi kebutuhan sumberdaya, misalnya kebutuhan akan karet alam maupun karet sisntetis. Di Thailand pada tahun 2012, manajemen ban limbah masih bias terhadap teknologi yang merusak (48,9\%), daripada pemulihan material yang melibatkan reklamasi karet, ban vulkanisir dan aplikasi ban utuh dan robek (6,7\%). Meskipun memiliki manfaat ekonomi dan lingkungan, 44,4\% ban bekas pada tahun 2012 dibuang di lingkungan terbuka, dan sisanya 0,05\% di tempat pembuangan sampah.[5] Peningkatan produksi ban vulkanisir serta diikuti tingginya penggunaan ban vulkanisir maka perlu dilakukan kajian yang bertujuan menentukan prosedur pemilihan ban vulkanisir dan menentukan umur pakai dari beberapa jenis ban vulkanisir yang digunakan pada kendaraan truk berdasaarkan ketentuan yang berlaku. Pemilihan ban vulkanisir yang tepat dapat menghindari risiko terjadinya kecelakaan ketikakendaraan beroperasi di jalan. Sehingga kendaraan yang berkeselamatan dapat terwujud.

\section{LANDASAN TEORI}

Ban merupakan komponen kendaraan yang komplek dalam strukturnya. Berikut adalah struktur dasar dari ban kendaraan. Kontruksi utama ban terdiridari lima komponen [3]. Tread adalah komponen yang terbuat dari campuran karet dan elemen ban yang bersentuhan dengan roda. Sidewall adalah komponen karet yang menutupi antara tread dan bead. Bodyply merupakan rangka dari ban yang terbuat dari sertabuatan, seperti poliester dan rayon. Be/t merupakan komponen ban yang memberikan kekakuan pada 
tread dan melindungi carcass. Bead merupakan bagian ban yang mencengkram pada pelek. Bead terdiri dari baja melingkar yang terbuat dari lilitan kawat baja, sehingga membuat bead mejadi sangat kuat.

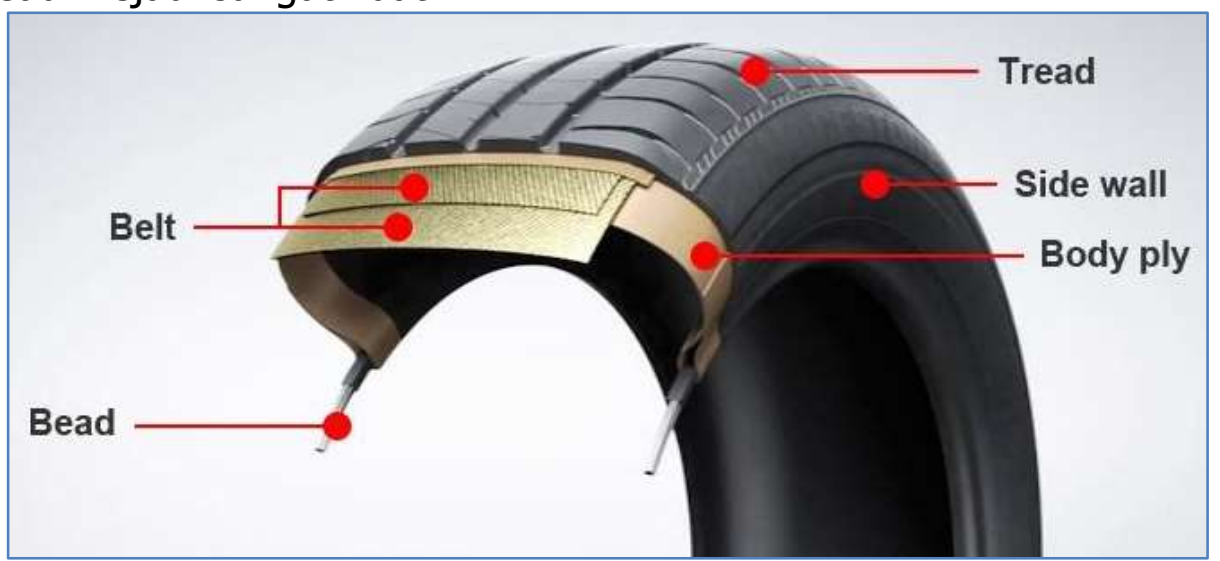

Gambar 1. Struktur ban [3]

Komposisi material dalam pembuatan ban akan ditemui berupa karet,bahan kimia dan struktural. Karet pada ban terdiri atas jenis karet alami (natural rubber) yang kebanyakan berasal dari pohon karet. Sifat-sifat karet alam termasuk ketahanan dan ketahanan abrasi. Karet sintetis (synthetic rubber), yang merupakan produk berbasis minyak bumi, memiliki sifat tahan panas. Bahan kimia yang dicampur dengan karet antara lain carbon black untuk menaikan kekuatan karet, silica menaikan efisiensi bahan bakar yang lebih baik dan cengkeraman basah, oil melunakan karet, antioxidant penghambat oksidasi karet, sulphur memberikan karet elastisitas yang lebih besar dan vulcanization accelerator membantu membangun ikatan silang antara karet dan belerang. Polyester digunakan sebagai bahan body ply pada ban penumpang, Rayon digunakan sebagai bahan ply body pada ban penumpang, Baja digunakan sebagai bahan dari beads dan beltsbaja di ban penumpang.

Ban vulkanisir dapat dikategorikan menjadi vulaknisir panas dan vulkanisir dingin. Keduanya dibedakan berdasarkan berdasarkan porses pembuatannya. Lebih lanjut porses pembuatan ban vulkanisir panas, 1 . Ban tiba di bengkel, dibersihkan dengan air sehingga kotoran, debu, dan lumpur harus dihilangkan secara efektif, 2. Ban dibiarkan beberapa saat agar kering atau kering dapat digunakan untuk tujuan ini, 3. Pemeriksaan awal dilakukan untuk memverifikasi bahwa casing dapat diterima untuk proses vulkanisir atau tidak. Ini benar-benar memeriksa dalam dan luar dan ditandai dengan krayon berwarn akuning, 4. Penggosok: - Tujuan utama penggosok adalah mempersiapkan permukaan ban yang aus untuk menerima vulkanisir. Desain tapak asli dan beberapa tapak bawah juga dilepas untuk memberikan casing dengan dimensi dan tekstur permukaan yang diperlukan. Dengan kata lain itu meningkatkan koefisien gesekan permukaan ban yang belum dibaca sehingga dapat memegang dengan kuat bantal dan sol tapak baru, 5. Ban terus berputar dan kedalaman sikat lukis dalam pelarut karet vulkanisasi ditempatkan di atas permukaan ban. Dengan cara ini menyebar secara seragam. Ambil lagi pelarut jika diperlukan. Setelah penerapan pelarut yang cukup, strip bantalan diperbaiki dan bandi putar perlahan sehingga lingkar ban tertutup dan kompon tapak tidak diawetkan diekstrusi atau diaplikasikan sebagai strip dengan panjang yang 
cukup langsung ke casing, 6. Ban ditempatkan di cetakan dan tekanan udara dipertahankan sehingga memperluas bahan tidak diawetkan mengambil posisi suhucetakan 150. C tapak dan setelah beberapa waktu cetakan dibuka dan ban diambil dari cetakan. Cetakan ini digunakan dalam pembuatan ban baru. Untuk setiap ukuran ban diperlukan cetakan baru sehingga merupakan proses yang mahal dan hampirusang.[1]

Sedangkan proses pembuatan ban vukanisir dingin, 1. Ban tiba di bengkel, dibersihkan dengan air sehingga kotoran, debu, dan lumpur harus dihilangkan secara efektif, 2. Ban dibiarkan beberapa saat agar kering atau kering dapat digunakan untuk tujuan ini, 3. Pemeriksaan awal dilakukan untuk memverifikasi bahwa casing dapat diterima untuk proses vulkanisir atau tidak. Ini benar-benar memeriksa dalam dan luar dan ditandai dengan krayon berwarna kuning, 4. Penggosok: - Tujuan utama penggosok adalah untuk mempersiapkan permukaan tapak ban yang aus untuk menerima vulkanisir. Desain tapak asli dan beberapa tapak bawah juga dihilangkan untuk memberikan casing dengan dimensi dan tekstur permukaan yang diperlukan. Dengan kata lain itu meningkatkan coefisien gesekan permukaan ban yang belum dibaca sehingga dapat memegang dengan kuat bantal dan sol tapak baru, 5. Ban terus berputar dan kedalaman sikat lukis dalam pelarut karet vulkanisasi ditempatkan di atas permukaan ban. Dengan cara ini menyebar secara seragam. Ambil lagi pelarut jika diperlukan. Setelah pengaplikasian pelarut secukupnya, strip bantalan diperbaiki dan ban diputar perlahan sehingga lingkar ban tertutup dan senyawa tapak yang tidak diawetkan diekstrusi atau diaplikasikan sebagai strip dengan panjang yang cukup langsung ke casing, 6 . Sekarang ban diturunkan dari mesin dan digantung di gantungan. Sampul ban di bawah penutup sehingga dalam proses pra-cetak bantal yang tidak diawetkan harus divulkanisir sementara tapakpracetakan harus dijaga posisinya. Ban dari gantungan digerakkan oleh kerekan dan rantai dan ditempatkan pada posisi tetap di Autoclavehorizontal (Autoclave adalah jenis tungku). Ujung nozzle tekanan udara terhubung ke tekanan udara amplop dipertahankan dan tutup tungku ditutup. Sebuah tombol ditekan. Suhu $99^{\circ} \mathrm{C}$ dipertahankan selama 3-4 jam. Tindakan ini menciptakan aksi rekatan atara lapisan, bantalan bantal dan sol tapak yang divulkanisir. Setelah 4 jam, pasokan listrik dimatikan dan biarkan dingin di tungku selama 1 hingga 2 jam. Ban dilepas dari tungku dan dibiarkan dingin sampai operator dapat melepaskan sampul, 7. Pemeriksaan akhir: - Untuk memastikan bahwa semua cacat yang ditemukan sebelum proses telah dihilangkan atau tidak. Jika ban lolos dari pemeriksaan akhir, maka ban tersebut disimpan di gudang untuk keperluan persediaan.[1]

Pengaturan tentang ban berdasarkan Surat Keputusan DirjenNomor: SK.2574/AJ.403/DRJD/2017 tentangPedomanPelaksanaanInspeksiKeselamatanLalu Lintas Dan Angkutan Jalan harus memenuhi persyratan berikut; tidak ada sayatan, tidak aa bagian yang mengelupas, idak ada benjolan atau penyokan, keempat ban harus memiliki ukuran yang sama dan kedalaman alur minimal $1 \mathrm{~mm}$ (satu milimeter) pada seluruh bagian ban. Pengecekan kedalaman alur minimal apabila tidak menggunakan alat adalah dengan melihat tanda atau simbol segitiga pada sisi luar ban original. Jika 
simbol segitiga sudah tidak utuh berarti kondisi kedalaman alur ban di bawah $1 \mathrm{~mm}$ (satu milimeter)

\section{METODE PENELITIAN}

Objek dari penelitian adalah ban vulkanisiryeng diterima dari empat produsen ban vulkanisir yaitu dari MJB, PJ, SMA dan BSB. Ban vulkanisir diujikan dipasang pada truk dengan jenis yang samakonfiurasi1.2.2 dan beban yang sama. Pemasangan banvulkanisirdilakukakan hanya pada sumbu kedua dan ketiga atau roda belakang, hal ini dikarenakan ban belakang tidak mengalami pembebanan berlebih ketika terjadi penegereman dan ban belakang bukan merupakan ban pengarah kendaraan sehingga sedikit mengalami pembebanan dalam arah lateral atau pembebanan yang timbul karena kendaraan berbelok. Metode pengujian pengukuran keausan ban dengan menggunakan ban secara langsung pada kendaraan dinamakan uji roadtest. Dimana ban diuji keausannya dengan kondisi jalandimana sesuai dengan jalur yang dilalui oleh kendaraan ketika beroperasi.

Pengukuran keausan terhadap ban vulkanisir dilakukan terhadap kedalaman dari alur treachan. Pengukuran tersebut dilakukan untuk mengetahui laju keausan dari ban vulkanisir. Dalam pengukuran untuk penelitian iniada beberapa batasan yang dilakukan, yaitu: tidak memperhatikan campuran dari bahan penyusun ban vulkanisir, proses pembuatan ban vulkanisir juga tidak ditentukan, pengukuran terhadap tekanan ban dilakukan untuk mengetahui bahwa tekanan ban sesuai dengan ketentuan, karakteristik jalan yang dilalui tidak dilakukan pengukuran untuk koefisien kekasarannya maupun kerataannya hanya memperhitungkan jarak tempuh yang telah dilalui oleh kendaraan serta tidak memperhatikan metode pengemudian namun demikian kendaraan yang digunakan dibatasi oleh lajunya sebesar $80 \mathrm{~km} / \mathrm{jam}$.

\section{PEMBAHASAN}

Data pengukuran terhadap keausan dilakukan dengan menggunakan tread depth gauge. Data diambil secara periodic tiap bulan. Pengambilan data dilakukan sampai hasil pengukuran ban vulkanisir mencapai $2 \mathrm{~mm}$. Berikut hasil pengukuran dari jarak tempuh dan keausantread dapat dilihat pada tabel 1, tabel 2 dan tabel 3.

Tabel 1. Data jaraktempuh dan keausan pada sumbu 2 rodasisiluarkanan-kiri

\begin{tabular}{|c|c|c|c|c|c|c|c|c|c|c|c|c|}
\hline \hline & \multicolumn{3}{|c|}{ Odomoter, km } & \multicolumn{3}{c|}{ 2LO, mm } & \multicolumn{3}{c|}{ Odomoter, km } & \multicolumn{3}{c|}{ 2RO, mm } \\
\cline { 2 - 12 } & Awal & Akhir & $\begin{array}{c}\text { Jara } \\
\mathbf{k}\end{array}$ & $\begin{array}{c}\text { Aw } \\
\text { al }\end{array}$ & $\begin{array}{c}\text { Akh } \\
\text { ir }\end{array}$ & $\begin{array}{c}\text { Keaus } \\
\text { an }\end{array}$ & Awal & Akhir & $\begin{array}{c}\text { Jara } \\
\text { k }\end{array}$ & $\begin{array}{c}\text { Aw } \\
\text { al }\end{array}$ & $\begin{array}{c}\text { Akh } \\
\text { ir }\end{array}$ & $\begin{array}{c}\text { Keaus } \\
\text { an }\end{array}$ \\
\hline \hline $\begin{array}{c}\text { MJ } \\
\text { B }\end{array}$ & $\begin{array}{c}590,1 \\
52\end{array}$ & $\begin{array}{c}635,4 \\
40\end{array}$ & $\begin{array}{c}45,2 \\
88\end{array}$ & 13.0 & 2.0 & 11.0 & $\begin{array}{c}590,1 \\
52\end{array}$ & $\begin{array}{c}615,2 \\
45\end{array}$ & $\begin{array}{c}25,0 \\
93\end{array}$ & 13.0 & 2.5 & 10.5 \\
\hline PJ & $\begin{array}{c}550,7 \\
76\end{array}$ & $\begin{array}{c}585,6 \\
53\end{array}$ & $\begin{array}{c}34,8 \\
77\end{array}$ & 13.0 & 2.0 & 11.0 & $\begin{array}{c}550,7 \\
76\end{array}$ & $\begin{array}{c}575,2 \\
98\end{array}$ & $\begin{array}{c}24,5 \\
22\end{array}$ & 13.0 & 3.0 & 10.0 \\
\hline $\begin{array}{c}\text { SM } \\
\text { A }\end{array}$ & $\begin{array}{c}700,1 \\
69\end{array}$ & $\begin{array}{c}720,6 \\
94\end{array}$ & $\begin{array}{c}20,5 \\
25\end{array}$ & 13.0 & 4.5 & 8.5 & $\begin{array}{c}700,1 \\
69\end{array}$ & $\begin{array}{c}72,6 \\
94\end{array}$ & $\begin{array}{c}20,5 \\
25\end{array}$ & 13.0 & 4.5 & 8.5 \\
\hline $\begin{array}{c}\text { BS } \\
\text { B }\end{array}$ & $\begin{array}{c}419,8 \\
43\end{array}$ & $\begin{array}{c}447,3 \\
83\end{array}$ & $\begin{array}{c}27,5 \\
40\end{array}$ & 13.0 & 3.0 & 10.0 & $\begin{array}{c}419,8 \\
43\end{array}$ & $\begin{array}{c}447,3 \\
83\end{array}$ & $\begin{array}{c}27,5 \\
40\end{array}$ & 13.0 & 2.5 & 10.5 \\
\hline
\end{tabular}

Tabel 2. Data jaraktempuh dan keausan pada sumbu3rodasisiluarkanan-kiri 


\begin{tabular}{|c|c|c|c|c|c|c|c|c|c|c|c|c|}
\hline \hline & \multicolumn{3}{|c|}{ Odomoter, km } & \multicolumn{3}{c|}{ 3LO, mm } & \multicolumn{3}{c|}{ Odomoter, km } & \multicolumn{3}{c|}{ 3RO, mm } \\
\cline { 2 - 12 } & Awal & Akhir & $\begin{array}{c}\text { Jara } \\
\mathbf{k}\end{array}$ & $\begin{array}{c}\text { Aw } \\
\text { al }\end{array}$ & $\begin{array}{c}\text { Akh } \\
\text { ir }\end{array}$ & $\begin{array}{c}\text { Keaus } \\
\text { an }\end{array}$ & Awal & Akhir & $\begin{array}{c}\text { Jara } \\
\text { k }\end{array}$ & $\begin{array}{c}\text { Aw } \\
\text { al }\end{array}$ & $\begin{array}{c}\text { Akh } \\
\text { ir }\end{array}$ & $\begin{array}{c}\text { Keaus } \\
\text { an }\end{array}$ \\
\hline \hline $\begin{array}{c}\text { MJ } \\
\text { B }\end{array}$ & $\begin{array}{c}590,1 \\
52\end{array}$ & $\begin{array}{c}620,9 \\
20\end{array}$ & $\begin{array}{c}30,7 \\
68\end{array}$ & 13.0 & 2.0 & 11.0 & $\begin{array}{c}590,1 \\
52\end{array}$ & $\begin{array}{c}620,9 \\
20\end{array}$ & $\begin{array}{c}30,7 \\
68\end{array}$ & $\begin{array}{c}13.0 \\
0\end{array}$ & 3.50 & 9.50 \\
\hline PJ & $\begin{array}{c}550,7 \\
76\end{array}$ & $\begin{array}{c}610,2 \\
32\end{array}$ & $\begin{array}{c}59,4 \\
56\end{array}$ & 13.0 & 4.0 & 9.0 & $\begin{array}{c}550,7 \\
76\end{array}$ & $\begin{array}{c}595,6 \\
84\end{array}$ & $\begin{array}{c}44,9 \\
08\end{array}$ & $\begin{array}{c}13.0 \\
0\end{array}$ & 4.00 & 9.00 \\
\hline $\begin{array}{c}\text { SM } \\
\text { A }\end{array}$ & $\begin{array}{c}700,1 \\
69\end{array}$ & $\begin{array}{c}739,9 \\
41\end{array}$ & $\begin{array}{c}39,7 \\
72\end{array}$ & 13.0 & 3.5 & 9.5 & $\begin{array}{c}700,1 \\
69\end{array}$ & $\begin{array}{c}729,0 \\
04\end{array}$ & $\begin{array}{c}28,8 \\
35\end{array}$ & $\begin{array}{c}13.0 \\
0\end{array}$ & 3.50 & 9.50 \\
\hline $\begin{array}{c}\text { BS } \\
\text { B }\end{array}$ & $\begin{array}{c}419,8 \\
43\end{array}$ & $\begin{array}{c}460,3 \\
54\end{array}$ & $\begin{array}{c}40,5 \\
11\end{array}$ & 13.0 & 3.0 & 10.0 & $\begin{array}{c}419,8 \\
43\end{array}$ & $\begin{array}{c}460,3 \\
54\end{array}$ & $\begin{array}{c}40,5 \\
11\end{array}$ & $\begin{array}{c}13.0 \\
0\end{array}$ & 3.50 & 9.50 \\
\hline
\end{tabular}

Tabel 3. Data jaraktempu dan keausan pada sumbu3rodasisidalamkanan-kiri

\begin{tabular}{|c|c|c|c|c|c|c|c|c|c|c|c|c|c|}
\hline \hline & \multicolumn{3}{|c|}{ Odomoter, km } & \multicolumn{4}{c|}{ 3LI, mm } & \multicolumn{3}{c|}{ Odomoter, km } & \multicolumn{3}{|c|}{ 3RI, mm } \\
\cline { 2 - 12 } & Awal & Akhir & $\begin{array}{c}\text { Jara } \\
\mathbf{k}\end{array}$ & $\begin{array}{c}\text { Aw } \\
\text { al }\end{array}$ & $\begin{array}{c}\text { Akh } \\
\text { ir }\end{array}$ & $\begin{array}{c}\text { Keaus } \\
\text { an }\end{array}$ & Awal & Akhir & $\begin{array}{c}\text { Jara } \\
\text { k }\end{array}$ & $\begin{array}{c}\text { Aw } \\
\text { al }\end{array}$ & $\begin{array}{c}\text { Akh } \\
\text { ir }\end{array}$ & $\begin{array}{c}\text { Keaus } \\
\text { an }\end{array}$ \\
\hline \hline $\begin{array}{c}\text { MJ } \\
\text { B }\end{array}$ & $\begin{array}{c}590,1 \\
52\end{array}$ & $\begin{array}{c}635,4 \\
40\end{array}$ & $\begin{array}{c}45,2 \\
88\end{array}$ & 13.0 & 2.5 & 10.5 & $\begin{array}{c}590,1 \\
52\end{array}$ & $\begin{array}{c}635,4 \\
40\end{array}$ & $\begin{array}{c}45,2 \\
88\end{array}$ & $\begin{array}{c}13.0 \\
0\end{array}$ & 2.00 & 11.00 \\
\hline PJ & $\begin{array}{c}550,7 \\
76\end{array}$ & $\begin{array}{c}610,2 \\
32\end{array}$ & $\begin{array}{c}59,4 \\
56\end{array}$ & 13.0 & 3.5 & 9.5 & $\begin{array}{c}550,7 \\
76\end{array}$ & $\begin{array}{c}610,2 \\
32\end{array}$ & $\begin{array}{c}59,4 \\
56\end{array}$ & $\begin{array}{c}13.0 \\
0\end{array}$ & 3.50 & 9.50 \\
\hline $\begin{array}{c}\text { SM } \\
\text { A }\end{array}$ & $\begin{array}{c}700,1 \\
69\end{array}$ & $\begin{array}{c}739,9 \\
41\end{array}$ & $\begin{array}{c}39,7 \\
72\end{array}$ & 13.0 & 4.0 & 9.0 & $\begin{array}{c}700,1 \\
69\end{array}$ & $\begin{array}{c}739,9 \\
41\end{array}$ & $\begin{array}{c}39,7 \\
72\end{array}$ & $\begin{array}{c}13.0 \\
0\end{array}$ & 4.00 & 9.00 \\
\hline $\begin{array}{c}\text { BS } \\
\text { B }\end{array}$ & $\begin{array}{c}419,8 \\
43\end{array}$ & $\begin{array}{c}460,3 \\
54\end{array}$ & $\begin{array}{c}40,5 \\
11\end{array}$ & 13.0 & 3.0 & 10.0 & $\begin{array}{c}419,8 \\
43\end{array}$ & $\begin{array}{c}460,3 \\
54\end{array}$ & $\begin{array}{c}40,5 \\
11\end{array}$ & $\begin{array}{c}13.0 \\
0\end{array}$ & 3.00 & 10.00 \\
\hline
\end{tabular}

Data pengukuran menunjukkan kedalaman tread ban awal menunjukkan nilai yang sama, yaitu $13 \mathrm{~mm}$. Namun terdapat perbedaan kedalaman tread ban pada akhir pengukuran,hal ini menunjukkan perbedaan tingkat keausan dari ban yang dipengaruhi oleh posisi dari ban pada kendaraan.

Untuk mempermudah perhitungan jarak tempuh maksimal yang dapat dicapai hingga kedalaman tread mencapai $2 \mathrm{~mm}$ maka digunakan rumus ekstrapolasi. Nilai $2 \mathrm{~mm}$ berdasarkan ketentuan bahwa batas minimal laik jalan untuk kedalaman ban adalah 1 $\mathrm{mm}$. Dengan perhitungan ekstrapolasi diperoleh hasil pada tabel 4, tabel 5 dan tabel 6 sebagai berikut;

Tabel 4. Konversijaraktempuhmaksimalkeausantread $2 \mathrm{~mm}$ pada sumbu 2 rodasisiluarkanan-kiri

\begin{tabular}{|c|c|c|c|c|c|c|c|c|c|c|c|c|c|}
\hline \hline & \multicolumn{2}{|c|}{ Odomoter, km } & \multicolumn{3}{c|}{$\mathbf{2 L O}, \mathbf{m m}$} & \multicolumn{3}{c|}{ Odomoter, km } & \multicolumn{3}{|c|}{ 2RO, mm } \\
\cline { 2 - 12 } & Awal & Akhir & $\begin{array}{c}\text { Jara } \\
\text { k }\end{array}$ & $\begin{array}{c}\text { Aw } \\
\text { al }\end{array}$ & $\begin{array}{c}\text { Akh } \\
\text { ir }\end{array}$ & $\begin{array}{c}\text { Keaus } \\
\text { an }\end{array}$ & Awal & Akhir & $\begin{array}{c}\text { Jara } \\
\text { k }\end{array}$ & $\begin{array}{c}\text { Aw } \\
\text { al }\end{array}$ & $\begin{array}{c}\text { Akh } \\
\text { ir }\end{array}$ & $\begin{array}{c}\text { Keaus } \\
\text { an }\end{array}$ \\
\hline \hline $\begin{array}{c}\text { MJ } \\
\text { B }\end{array}$ & $\begin{array}{c}590,1 \\
52\end{array}$ & $\begin{array}{c}635,4 \\
40\end{array}$ & $\begin{array}{c}45,2 \\
88\end{array}$ & 13.0 & 2.0 & 11.0 & $\begin{array}{c}590,1 \\
52\end{array}$ & $\begin{array}{c}616,4 \\
40\end{array}$ & $\begin{array}{c}26,2 \\
88\end{array}$ & 13.0 & 2.0 & 11.0 \\
\hline PJ & $\begin{array}{c}550,7 \\
76\end{array}$ & $\begin{array}{c}585,6 \\
53\end{array}$ & $\begin{array}{c}34,8 \\
77\end{array}$ & 13.0 & 2.0 & 11.0 & $\begin{array}{c}550,7 \\
76\end{array}$ & $\begin{array}{c}577,7 \\
50\end{array}$ & $\begin{array}{c}26,9 \\
74\end{array}$ & 13.0 & 2.0 & 11.0 \\
\hline $\begin{array}{c}\text { SM } \\
\text { A }\end{array}$ & $\begin{array}{c}700,1 \\
69\end{array}$ & $\begin{array}{c}726,7 \\
31\end{array}$ & $\begin{array}{c}26,5 \\
62\end{array}$ & 13.0 & 2.0 & 11.0 & $\begin{array}{c}700,1 \\
69\end{array}$ & $\begin{array}{c}726,7 \\
31\end{array}$ & $\begin{array}{c}26,5 \\
62\end{array}$ & 13.0 & 2.0 & 11.0 \\
\hline $\begin{array}{c}\text { BS } \\
\text { B }\end{array}$ & $\begin{array}{c}419,8 \\
43\end{array}$ & $\begin{array}{c}450,1 \\
37\end{array}$ & $\begin{array}{c}30,2 \\
94\end{array}$ & 13.0 & 2.0 & 11.0 & $\begin{array}{c}419,8 \\
43\end{array}$ & $\begin{array}{c}448,6 \\
94\end{array}$ & $\begin{array}{c}28,8 \\
51\end{array}$ & 13.0 & 2.0 & 11.0 \\
\hline
\end{tabular}


Tabel 5. Konversijaraktempuhmaksimalkeausantread $2 \mathrm{~mm}$ pada sumbu 3 rodasisiluarkanan-kiri

\begin{tabular}{|c|c|c|c|c|c|c|c|c|c|c|c|c|}
\hline \hline & \multicolumn{3}{|c|}{ Odomoter, km } & \multicolumn{3}{c|}{ 3LO, mm } & \multicolumn{3}{c|}{ Odomoter, km } & \multicolumn{3}{|c|}{ 3RO, mm } \\
\cline { 2 - 12 } & Awal & Akhir & $\begin{array}{c}\text { Jara } \\
\mathbf{k}\end{array}$ & $\begin{array}{c}\text { Aw } \\
\text { al }\end{array}$ & $\begin{array}{c}\text { Akh } \\
\text { ir }\end{array}$ & $\begin{array}{c}\text { Keaus } \\
\text { an }\end{array}$ & Awal & Akhir & $\begin{array}{c}\text { Jara } \\
\mathbf{k}\end{array}$ & $\begin{array}{c}\text { Aw } \\
\text { al }\end{array}$ & $\begin{array}{c}\text { Akh } \\
\text { ir }\end{array}$ & $\begin{array}{c}\text { Keaus } \\
\text { an }\end{array}$ \\
\hline \hline $\begin{array}{c}\text { MJ } \\
\text { B }\end{array}$ & $\begin{array}{c}590,1 \\
52\end{array}$ & $\begin{array}{c}620,9 \\
20\end{array}$ & $\begin{array}{c}30,7 \\
68\end{array}$ & 13.0 & 2.0 & 11.0 & $\begin{array}{c}590,1 \\
52\end{array}$ & $\begin{array}{c}625,7 \\
78\end{array}$ & $\begin{array}{c}35,6 \\
26\end{array}$ & $\begin{array}{c}13.0 \\
0\end{array}$ & 2.00 & 11.00 \\
\hline PJ & $\begin{array}{c}550,7 \\
76\end{array}$ & $\begin{array}{c}623,4 \\
44\end{array}$ & $\begin{array}{c}72,6 \\
68\end{array}$ & 13.0 & 2.0 & 11.0 & $\begin{array}{c}550,7 \\
76\end{array}$ & $\begin{array}{c}605,6 \\
64\end{array}$ & $\begin{array}{c}54,8 \\
88\end{array}$ & $\begin{array}{c}13.0 \\
0\end{array}$ & 2.00 & 11.00 \\
\hline $\begin{array}{c}\text { SM } \\
\text { A }\end{array}$ & $\begin{array}{c}700,1 \\
69\end{array}$ & $\begin{array}{c}746,2 \\
21\end{array}$ & $\begin{array}{c}46,0 \\
52\end{array}$ & 13.0 & 2.0 & 11.0 & $\begin{array}{c}700,1 \\
69\end{array}$ & $\begin{array}{c}733,5 \\
57\end{array}$ & $\begin{array}{c}33,3 \\
88\end{array}$ & $\begin{array}{c}13.0 \\
0\end{array}$ & 2.00 & 11.00 \\
\hline $\begin{array}{c}\text { BS } \\
\text { B }\end{array}$ & $\begin{array}{c}419,8 \\
43\end{array}$ & $\begin{array}{c}464,4 \\
05\end{array}$ & $\begin{array}{c}44,5 \\
62\end{array}$ & 13.0 & 2.0 & 11.0 & $\begin{array}{c}419,8 \\
43\end{array}$ & $\begin{array}{c}466,7 \\
50\end{array}$ & $\begin{array}{c}46,9 \\
07\end{array}$ & $\begin{array}{c}13.0 \\
0\end{array}$ & 2.00 & 11.00 \\
\hline
\end{tabular}

Tabel 6. Konversijaraktempuhmaksimalkeausantread $2 \mathrm{~mm}$ pada sumbu 3 rodasisiluarkanan-kiri

\begin{tabular}{|c|c|c|c|c|c|c|c|c|c|c|c|c|}
\hline \hline & \multicolumn{3}{|c|}{ Odomoter, km } & \multicolumn{3}{|c|}{ 3LI, mm } & \multicolumn{3}{c|}{ Odomoter, km } & \multicolumn{3}{|c|}{ 3RI, mm } \\
\cline { 2 - 12 } & Awal & Akhir & $\begin{array}{c}\text { Jara } \\
\mathbf{k}\end{array}$ & $\begin{array}{c}\text { Aw } \\
\text { al }\end{array}$ & $\begin{array}{c}\text { Akh } \\
\text { ir }\end{array}$ & $\begin{array}{c}\text { Keaus } \\
\text { an }\end{array}$ & Awal & Akhir & $\begin{array}{c}\text { Jara } \\
\mathbf{k}\end{array}$ & $\begin{array}{c}\text { Aw } \\
\text { al }\end{array}$ & $\begin{array}{c}\text { Akh } \\
\text { ir }\end{array}$ & $\begin{array}{c}\text { Keaus } \\
\text { an }\end{array}$ \\
\hline \hline $\begin{array}{c}\text { MJ } \\
\text { B }\end{array}$ & $\begin{array}{c}590,1 \\
52\end{array}$ & $\begin{array}{c}637,5 \\
97\end{array}$ & $\begin{array}{c}47,4 \\
45\end{array}$ & 13.0 & 2.0 & 11.0 & $\begin{array}{c}590,1 \\
52\end{array}$ & $\begin{array}{c}635,4 \\
40\end{array}$ & $\begin{array}{c}45,2 \\
88\end{array}$ & $\begin{array}{c}13.0 \\
0\end{array}$ & 2.00 & 11.00 \\
\hline PJ & $\begin{array}{c}550,7 \\
76\end{array}$ & $\begin{array}{c}619,6 \\
20\end{array}$ & $\begin{array}{c}68,8 \\
44\end{array}$ & 13.0 & 2.0 & 11.0 & $\begin{array}{c}550,7 \\
76\end{array}$ & $\begin{array}{c}619,6 \\
20\end{array}$ & $\begin{array}{c}68,8 \\
44\end{array}$ & $\begin{array}{c}13.0 \\
0\end{array}$ & 2.00 & 11.00 \\
\hline $\begin{array}{c}\text { SM } \\
\text { A }\end{array}$ & $\begin{array}{c}700,1 \\
69\end{array}$ & $\begin{array}{c}748,7 \\
79\end{array}$ & $\begin{array}{c}48,6 \\
10\end{array}$ & 13.0 & 2.0 & 11.0 & $\begin{array}{c}700,1 \\
69\end{array}$ & $\begin{array}{c}748,7 \\
79\end{array}$ & $\begin{array}{c}48,6 \\
10\end{array}$ & $\begin{array}{c}13.0 \\
0\end{array}$ & 2.00 & 11.00 \\
\hline $\begin{array}{c}\text { BS } \\
\text { B }\end{array}$ & $\begin{array}{c}419,8 \\
43\end{array}$ & $\begin{array}{c}464,4 \\
05\end{array}$ & $\begin{array}{c}44,5 \\
62\end{array}$ & 13.0 & 2.0 & 11.0 & $\begin{array}{c}419,8 \\
43\end{array}$ & $\begin{array}{c}464,4 \\
05\end{array}$ & $\begin{array}{c}44,5 \\
62\end{array}$ & $\begin{array}{c}13.0 \\
0\end{array}$ & 2.00 & 11.00 \\
\hline
\end{tabular}

Jika memperhatikan jarak maksimal yang dapat ditempuh dan keausan yang terjadi maka ban vulkanisir dari PJ yang dipasang pada sumbu ketiga kanan sisi dalam maupun kiri sisi luar jarak tempuh sejauh 68,844 km agar kedalaman ban yang tersisa $2 \mathrm{~mm}$. Namun jika memperhatikan rata-rata jarak tempuh ban vulkanisir maka ban dari PJ dapat menempuh jarak sejauah 54,516 km

Tabel 7. Jaraktempuh rata-rata ban vulkanisir

\begin{tabular}{|c|c|c|c|}
\hline \multirow{2}{*}{} & \multicolumn{3}{|c|}{ Jarak, km } \\
\cline { 2 - 4 } & Kiri & Kanan & Rerata \\
\hline \hline MJB & 41,167 & 35,734 & 38,450 \\
\hline PJ & 58,796 & 50,235 & 54,516 \\
\hline SMA & 40,408 & 36,187 & 38,297 \\
\hline BSB & 39,806 & 40,107 & 39,957 \\
\hline
\end{tabular}

Jika diketahui harga dari ban vulkanisir yang tertera pada tabel 8, maka dapat ditentukan biaya tiap kilometre dari kebutuhan ban vulkanisir. Hasil perhitungan dari biaya ban vulkanisir per kilometre ditunjukkan pada tabel 8. Kalau diperhatikan harga ban vulkanisir PJ memiliki harga yang relative lebih mahal namun demikian jarak tempuh yang dapat dicapai paling maksimal.

Tabel 8. Biaya per kilometer ban vulkanisir 


\begin{tabular}{|c|cc|c|c|}
\hline \multirow{2}{*}{} & \multicolumn{4}{|c|}{ Biaya per kilometer } \\
\cline { 2 - 5 } & \multicolumn{2}{|c|}{ Harga, Rp } & $\begin{array}{c}\text { Rerata, } \\
\text { km }\end{array}$ & CPK \\
\hline \hline MJB & $\mathrm{Rp}$ & 600,000 & 38,450 & $\mathrm{Rp} 15.6$ \\
\hline PJ & $\mathrm{Rp}$ & 625,000 & 54,516 & $\begin{array}{c}\mathrm{Rp} \\
11.5\end{array}$ \\
\hline SMA & $\mathrm{Rp}$ & 550,000 & 38,297 & $\begin{array}{c}\mathrm{Rp} \\
14.4\end{array}$ \\
\hline BSB & $\mathrm{Rp}$ & 645,455 & 39,957 & $\begin{array}{c}\mathrm{Rp} \\
16.2\end{array}$ \\
\hline
\end{tabular}

Perhitungan biaya per kilometer ban vulkanisir merupakan salah satu biaya yang akan mempengaruhi biaya operasioanal dari kendaraan.

\section{KESIMPULAN}

Pemilihan terhadap penggunaan ban vulkanisir dapat dilakukan dengan metode roadtest. Pemilihan ban vulkanisir tidak hanya memperhatikan factor ekonomi tetapi tetap memperhatikan factor keselamatan, yaitu ambang batas kedalaman tread ban tidak kurang dari $1 \mathrm{~mm}$. Biaya per kilometre dari ban vulkanisir dapat ditentukan dengan membandingkan harga dari ban vulkanisir dengan jarak tempuh dari ban vulkanisir sebelum mencapai nilai ambang batasnya. Biaya dari ban vulkanisir akan menentukan biaya operational kendaraan.

\section{UCAPANTERIMAKASIH}

Penghargaan kepada PT. JTI, khususnya kepada bapak M. Solihin, Nor Sukoco, Fathur dan Joko atas dukungan dan fasilitas yang diberikan sehingga penelitian ini dapat terselesaikan dengan baik.

\section{DAFTAR PUSTAKA}

Anurag Sharma (2013), Retreading of Tyres, International Journal of Engineering and Advanced Technology (IJEAT), 2, 143-145

Bisnis Indonesia.com, 29 Juli 2019, DAYA SAING PRODUK : Standardisasi Ban Vulkanisir Disiapkan, diakses 20 September 2019, https://koran.bisnis.com/read/20190729/447/1129654/daya-saing-produk standardisasi-ban-vulkanisir-disiapkan

Bridgestone.com (2019), Basic knowledge of tires,diaksestanggal 20 September 2019, https://www.bridgestone.com/products/basic_knowledge/Detik.com, 15 September 2019, Bahaya Ban PecahSampaiSebabkanKecelakaanMaut di Jagorawi, diaksestanggal 17 September 2019, https://oto.detik.com/mobil/d-4707185/bahayaban-pecah-sampai-sebabkan-kecelakaan-maut-di-jagorawi

Paul Jacob, Prakriti Kashyap, TasawanSuparat and Chettiyappan Visvanathan (2014), Dealing with emerging waste streams: Used tyre assessment in Thailand using material flow analysis, Waste Management \& Research, 32(9) 918-926 